\title{
What is the optimal radiotherapy utilization rate for lung cancer? - a systematic review
}

\author{
Wei Liu ${ }^{1}$, Alissa Liu ${ }^{2}$, Jessica Chan ${ }^{3}$, R. Gabriel Boldt ${ }^{1}$, Pablo Munoz-Schuffenegger ${ }^{4}$, Alexander V. Louie ${ }^{1,5}$ \\ ${ }^{1}$ Division of Radiation Oncology, London Health Sciences Centre, London, Ontario, Canada; ${ }^{2}$ McMaster University, Hamilton, Ontario, Canada; \\ ${ }^{3}$ Division of Radiation Oncology, The Ottawa Hospital and the University of Ottawa, Ottawa, Ontario, Canada; ${ }^{4}$ Departamento de Hematologia- \\ Oncologia, Pontificia Universidad Catolica de Chile, Santiago, Región Metropolitana, Chile; ${ }^{5}$ Department of Radiation Oncology, Sunnybrook \\ Health Sciences Centre, Toronto, Ontario, Canada \\ Contributions: (I) Conception and design: W Liu, A Liu, P Munoz-Schuffenegger, AV Louie; (II) Administrative support: None; (III) Provision of \\ study materials or patients: All authors; (IV) Collection and assembly of data: W Liu, A Liu; (V) Data analysis and interpretation: All authors; (VI) \\ Manuscript writing: All authors; (VII) Final approval of manuscript: All authors. \\ Correspondence to: Alexander V. Louie. Department of Radiation Oncology, Sunnybrook Health Sciences Centre, 2075 Bayview Ave. T2 163, Toronto, \\ ON, M4N 3M5, Canada. Email: Alexander.Louie@sunnybrook.ca.
}

\begin{abstract}
Lung cancer is a major cause of morbidity and mortality globally. Although radiotherapy (RT) may be beneficial in the radical and/or palliative management of many lung cancer patients, it is underutilized worldwide. Population-level development of RT resources requires estimates of optimal radiotherapy utilization rates (ORUR) and actual radiotherapy utilization rate (ARUR). A systematic review of PubMed database for English-language articles from January 2009 to January 2019 was performed. Keywords included utilization, underutilization, demand, epidemiologic, benchmark, RT and cancer. Data abstracted included: study population, diagnosis, stage, year of diagnosis, timing of RT, intent of RT, ARUR, and ORUR. Eligible studies provided ARUR or ORUR for lung cancer, small cell lung cancer (SCLC), or nonsmall cell lung cancer (NSCLC). Included ARUR were based on at least 1,000 patients who were diagnosed or treated in 2009 or later. Included ORUR were based on evidence review or ARUR in 2009 or later. The initial search strategy yielded 1,627 unique abstracts. After review, 105 articles were determined appropriate for full-text review. From these, a final set of 21 articles met all inclusion criteria. In eight papers, ORUR was estimated. Estimated lifetime ORUR ranged from $61 \%$ to $82 \%$. Methods for estimation included the evidence-based guideline model, Malthus model, and criterion-based benchmarking (CBB) model. The majority of estimates (6/8) used the evidence-based guideline model. Fifteen papers provided ARUR on lung cancer, inclusive of SCLC and NSCLC. ARUR within 9 months to 1 year of diagnosis ranged from $39 \%$ to 46\%. Lifetime ARUR was an estimated 52\% in Ontario, Canada. Palliative intent ARUR ranged from 12\% in Central Poland to 46\% in Ontario, Canada. RT is underutilized for lung cancer globally, and there is wide geographical variation in the level of underutilization.
\end{abstract}

Keywords: Lung neoplasms; radiotherapy (RT); systematic review; global health

Submitted Aug 08, 2019. Accepted for publication Aug 12, 2019.

doi: $10.21037 /$ tlcr.2019.08.12

View this article at: http://dx.doi.org/10.21037/tlcr.2019.08.12

\section{Introduction}

Lung cancer has the highest global incidence among cancers excluding nonmelanoma skin cancer and the highest mortality (1). Radiotherapy (RT) is an effective, evidence-based, and guideline-recommended treatment for patients with lung cancer, both for improving outcomes and for palliating symptoms such as shortness of breath, bleeding and pain (2-6). However, RT is underdeveloped and underutilized worldwide, especially in low-and middle- 
income countries (LMIC) (7). This has been estimated to cause significant excess morbidity and mortality across a range of cancers, including lung cancer (8).

Expansion of RT resources is complex and costly, but can be cost-effective when planned appropriately (7). Optimal radiotherapy utilization rate (ORUR) and actual radiotherapy utilization rate (ARUR) are common metrics used to forecast such planning. ORUR is the percentage of patients for whom RT is indicated as a treatment option at least once during a time period, and ARUR is the percentage of patients who actually received RT during a time period. The gap between ORUR and ARUR, combined with data on fractionation, retreatment, and incidence for each cancer type, can be used to estimate the unmet demand for RT. In this study, we perform a systematic review of reported ORUR and ARUR for lung cancer.

\section{Methods}

A systematic review of the literature was performed per the Preferred Reporting Items for Systematic Review and Meta-analysis (PRISMA) guidelines (9). PubMed was searched in January 2019 for articles in English from January 2009 to January 2019. A search strategy was performed using keywords including "utilization", or "underutilization", or "demand", or "epidemiologic", or "benchmark", and "radiotherapy", or "radiation therapy", or "irradiation" or "cancer". Title and abstracts were screened for full-text review independently by W Liu and A Liu, with discrepancies settled by consensus. The bibliographies of identified articles were also searched for potential additional studies. Eligible studies provided ARUR or ORUR for lung cancer, small cell lung cancer (SCLC), or non-small cell lung cancer (NSCLC). Included ARUR were based on at least 1,000 patients who were diagnosed or treated in 2009 or later. Included ORUR were based on evidence review or ARUR in 2009 or later. Fulltext review was performed on remaining articles and articles were excluded where appropriate. Data abstracted from the final articles for inclusion included: study details (source of patient data, sample size), patient details (diagnosis, stage, time of diagnosis), treatment details (time of RT, intent of RT, ARUR, and ORUR) and finally methodological details (method used for estimating ORUR). Data abstraction included estimated values from figures where corresponding numerical values were not presented.

\section{Results}

The initial search strategy yielded 1,627 unique abstracts. After title and abstract review, 105 articles were determined to be appropriate for a full-text review. From these, a final set of 21 articles met all inclusion criteria and were suitable for data abstraction (Figure 1).

Of the eight papers that estimated ORUR for lung cancer (Table 1) (7,10-16), six used an evidence-based methodology (7,10-14), one used the Malthus model (15) and one used criterion-based benchmarking (CBB) (16). Two of the six papers that conducted evidence-based estimates of ORUR were performed by the Australian Collaboration for Cancer Outcomes Research and Evaluation (CCORE) group and included systematic reviews of indications for RT $(10,11)$. The remaining four papers were based on the CCORE model and applied different epidemiological data $(7,12-14)$.

Lifetime ORUR for lung cancer were 61\% in England using the Malthus model, $62 \%$ in Ontario, Canada using $\mathrm{CBB}$, and $77 \%$ to $82 \%$ using the CCORE evidence-based model. Evidence-based estimates of lifetime ORUR for NSCLC and SCLC were $80 \%$ and 59\%, respectively (11).

Fifteen papers presented ARUR on lung cancer, SCLC, or NSCLC, including overall ARUR (Table 2), palliative intent ARUR (Table 3), and curative intent ARUR (Table 4) (14,16-29). Measured lifetime ARUR was not available, but lifetime ARUR was estimated using the multicohort utilization table (MCUT) method in Ontario, Canada to be $52 \%$ (11). Observation period and method used to calculate ARUR were inconsistent.

Overall ARUR for lung cancer was presented in 6 papers and ranged from $22 \%$ in Central Poland to $52 \%$ in Ontario, Canada. Overall ARUR for Stage IA NSCLC in the United States of America (USA) increased from 21\% in 2009 to $29 \%$ in 2012. Overall ARUR for stage I SCLC in the USA ranged from $44 \%$ to $53 \%$ between 2009 and 2013. Four papers presented palliative intent ARUR ranging from $12 \%$ in Central Poland to $47 \%$ in Norway. Six papers presented curative intent ARUR on lung cancer, SCLC, or NSCLC. Curative intent RT was variably defined. Curative intent ARUR for stage I SCLC in the USA was $36 \%$ to $38 \%$. Stereotactic body radiotherapy (SBRT) use for stage I SCLC in the USA increased from $3 \%$ to $6 \%$ and conventional external beam radiotherapy (EBRT) decreased between 2009 and 2013 in the USA. For stage I NSCLC, curative intent ARUR was $12 \%$ in Europe and England, and 7\% to $13 \%$ of patients in the USA underwent SBRT. 


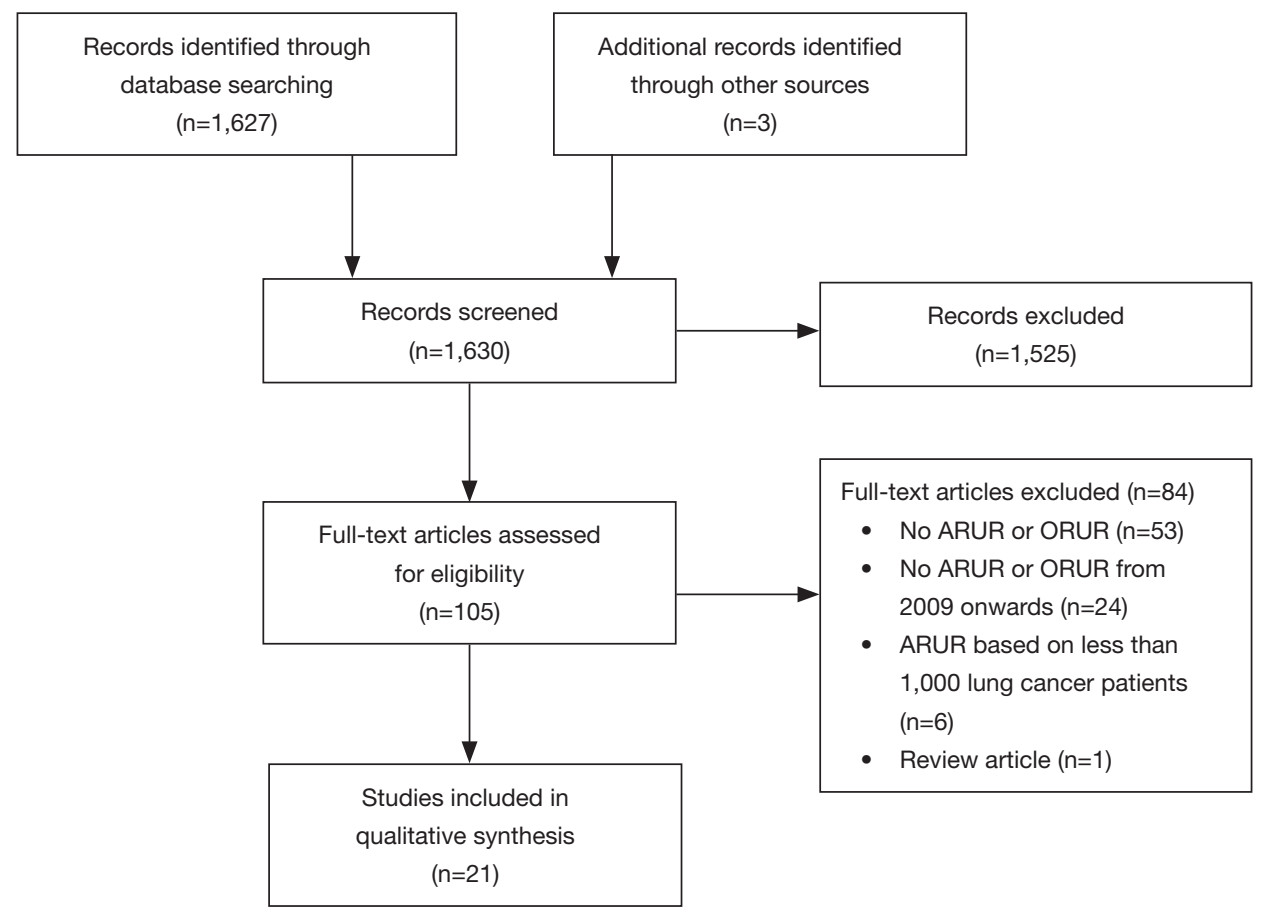

Figure 1 Flow chart of the article search strategy and systematic review process according to PRISMA guidelines. PRISMA, Preferred Reporting Items for Systematic Reviews and Meta-Analyses; ARUR, actual radiotherapy utilization rate; ORUR, optimal radiotherapy utilization rate.

Table 1 Studies reporting ORUR in lung cancer patients

\begin{tabular}{|c|c|c|c|c|c|c|c|}
\hline Author [year] & Method used & Cancer Registry & Year of diagnosis & ORUR & Diagnosis & Time of RT & Notes \\
\hline Barton [2014] & Evidence-based & Australia & 2008 & $77 \%$ & Lung cancer & Lifetime & $\begin{array}{l}\text { Evidence review } \\
\text { performed }\end{array}$ \\
\hline \multirow{2}{*}{ Shafiq [2016] } & \multirow{2}{*}{ Evidence-based } & \multirow{2}{*}{ Australia } & \multirow{2}{*}{2008} & $80 \%$ & NSCLC & \multirow{2}{*}{ Lifetime } & \multirow{2}{*}{$\begin{array}{l}\text { Evidence review } \\
\text { performed }\end{array}$} \\
\hline & & & & $59 \%$ & SCLC & & \\
\hline Atun [2015] & Evidence-based & $\begin{array}{l}\text { global (GLOBOCAN } \\
\text { 2012) }\end{array}$ & 2012 & $77 \%$ & Lung cancer & Lifetime & $\begin{array}{l}\text { Based on CCORE } \\
\text { model (10) }\end{array}$ \\
\hline \multirow[t]{2}{*}{ Borras [2015] } & \multirow[t]{2}{*}{ Evidence-based } & Belgium & 2010-2011 & $77 \%$ & \multirow[t]{2}{*}{ Lung cancer } & \multirow[t]{2}{*}{ Lifetime } & \multirow{2}{*}{$\begin{array}{l}\text { Based on CCORE } \\
\text { model (10) }\end{array}$} \\
\hline & & Netherlands & 2010-2011 & $78 \%$ & & & \\
\hline Round [2013] & Malthus Model & England & 2007-2009 & $61 \%$ & Lung cancer & Lifetime & $\begin{array}{l}\text { Evidence review } \\
\text { performed }\end{array}$ \\
\hline \multirow[t]{2}{*}{ Mackillop [2015] } & CBB & Ontario, Canada & 2009-2011 & $54 \%$ & Lung cancer & 1 year & \\
\hline & & & & $62 \%$ & & Lifetime & \\
\hline
\end{tabular}

ORUR, optimal radiotherapy utilization rate; CCORE, Collaboration for Cancer Outcomes Research and Evaluation; CBB, criterion-based benchmarking; NSCLC, non-small cell lung cancer; SCLC, small-cell lung cancer. 
Table 2 Studies reporting overall ARUR in lung cancer patients

\begin{tabular}{|c|c|c|c|c|c|c|}
\hline Author [year] & Diagnosis & $\begin{array}{l}\text { Number } \\
\text { diagnosed }\end{array}$ & Cancer registry & Year of diagnosis & Overall ARUR & Time of RT \\
\hline Asli [2014] & Lung cancer & 2,784 & Norway & 2009 & $44 \%$ & $\begin{array}{l}\text { Within } 1 \text { year of } \\
\text { diagnosis }\end{array}$ \\
\hline $\begin{array}{l}\text { Chalubinska- } \\
\text { Fendler [2015] }\end{array}$ & Lung cancer & 1,307 & Central Poland & 2009-2012 & $\begin{array}{l}\text { 2009: } 24 \% ; 2010: \\
\text { 25\%; } 2011: 22 \% \text {; } \\
2012: 27 \%\end{array}$ & 2009-2012 \\
\hline \multirow[t]{2}{*}{ Lievens [2017] } & Lung cancer & 14,417 & Belgium & 2009-2010 & $39 \%$ & $\begin{array}{l}\text { Within } 9 \text { months of } \\
\text { diagnosis }\end{array}$ \\
\hline & & & & & $46 \%$ & $\begin{array}{l}\text { Within } 4-5 \text { years of } \\
\text { diagnosis }\end{array}$ \\
\hline McLaughlin [2018] & & & & & $52 \%$ & $\begin{array}{l}\text { Estimated lifetime } \\
\text { ARUR using MCUT } \\
\text { method }\end{array}$ \\
\hline Seo [2018] & Lung cancer & 50,384 & South Korea & 2011-2015 & $\begin{array}{l}2011: 41 \% \\
2014: 45 \%\end{array}$ & 2011-2015 \\
\hline Carrato [2014] & NSCLC & 3,508 & $\begin{array}{l}\text { Prospective study of } \\
182 \text { cancer centres } \\
\text { in Belgium, France, } \\
\text { Germany, Turkey, } \\
\text { Greece, Italy, Portugal } \\
\text { and Spain }\end{array}$ & $\begin{array}{l}\text { January-March } \\
2009\end{array}$ & $\begin{array}{l}\text { Stage I-II: } 23 \% \text {; } \\
\text { stage III: } 50 \% \text {; } \\
\text { stage IV: } 35 \% \text {; } \\
\text { overall: } 37 \%\end{array}$ & $\begin{array}{l}\text { Followed prospectively } \\
\text { for a minimum of } 1 \text { year } \\
\text { or until death }\end{array}$ \\
\hline Ahmed [2017] & SCLC, stage I & 1,902 & USA (SEER) & 2007-2013 & $\begin{array}{l}\text { 2009: 49\%; 2010: } \\
\text { 53\%; 2011: 47\%; } \\
\text { 2012: 44\%; 2013: } \\
50 \%\end{array}$ & 2007-2013 \\
\hline
\end{tabular}

ARUR, actual radiotherapy utilization rate; NSCLC, non-small cell lung cancer; SCLC, small-cell lung cancer; SEER, Surveillance, Epidemiology, and End Results; RT, radiotherapy; MCUT, multicohort utilization table.

\section{Discussion}

Lung cancer is the second most common indication for RT globally (7) and has consistently been demonstrated to be the most common indication for palliative RT $(18,24,25)$. In this systematic review, we summarized ARUR and ORUR metrics for lung cancer, and found that lung RT remains underutilized. As lung RT has been demonstrated to be cost-effective $(7,30)$, we would advocate that strategies to optimize its utilization should be prioritized.

Lifetime ORUR for lung RT ranged from $61 \%$ to $82 \%$. Evidence-based estimates, the Malthus Model, and CBB are three methods used to estimate lung ORUR, and each has associated strengths and weaknesses. Evidence-based 
Table 3 Studies reporting palliative intent ARUR in lung cancer patients

\begin{tabular}{|c|c|c|c|c|c|c|}
\hline Author [year] & Histology & $\begin{array}{l}\text { Number } \\
\text { diagnosed }\end{array}$ & Cancer registry & $\begin{array}{l}\text { Year of diagnosis } \\
\text { or death }\end{array}$ & Palliative-intent ARUR & $\begin{array}{l}\text { Time of palliative- } \\
\text { intent ARUR }\end{array}$ \\
\hline $\begin{array}{l}\text { Chalubinska- } \\
\text { Fendler [2015] }\end{array}$ & Lung cancer & 1,307 & Central Poland & $\begin{array}{l}\text { Diagnosis: } \\
\text { 2009-2012 }\end{array}$ & $\begin{array}{l}\text { 2009: 16\%; 2010: 17\%; } \\
\text { 2011: 12\%; 2012: 12\% }\end{array}$ & 2009-2012 \\
\hline \multirow[t]{2}{*}{ Huang [2014] } & \multirow[t]{2}{*}{ Lung cancer } & \multirow[t]{2}{*}{2,406} & \multirow[t]{2}{*}{ British Columbia, Canada } & \multirow{2}{*}{$\begin{array}{l}\text { Death: April } \\
\text { 2010-March } 2011\end{array}$} & $46 \%$ & Last year of life \\
\hline & & & & & $25 \%$ & Last 30 days \\
\hline Asli [2018] & Lung cancer & 5,260 & Norway & $\begin{array}{l}\text { Death: July 2009- } \\
\text { December } 2011\end{array}$ & $47 \%$ & Last 2 years life \\
\hline Carrato [2014] & NSCLC & 3,508 & $\begin{array}{l}\text { Prospective study of } \\
182 \text { cancer centres } \\
\text { in Belgium, France, } \\
\text { Germany, Turkey, Greece, } \\
\text { Italy, Portugal and Spain }\end{array}$ & $\begin{array}{l}\text { Diagnosis: } \\
\text { January-March } \\
2009\end{array}$ & $\begin{array}{l}\text { Stage I: } 6 \% \text {; stage II: } 7 \% \text {; } \\
\text { stage III: } 14 \% \text {; stage IV: } \\
28 \% \text {; overall: } 20 \%\end{array}$ & $\begin{array}{l}\text { Followed } \\
\text { prospectively for a } \\
\text { minimum of } 1 \text { year or } \\
\text { until death }\end{array}$ \\
\hline
\end{tabular}

ARUR, actual radiotherapy utilization rate; NSCLC, non-small cell lung cancer.

estimates are based on a systematic review to determine indications for RT and estimates of the incidence of each indication in a population. Advantages include transparent methodology and the flexibility to adapt the model to different populations and with changes to indications (31). One weakness of the model is reliance on epidemiological data, which may vary in quality. Population-based registries frequently do not include information such as surgical margins, comorbidities and performance status, and this data may be excluded or estimated from less representative sources (31).

The Malthus model uses the evidence-based estimate method and Monte-Carlo simulation. In the one study using Malthus, results were based on local and regional epidemiological data in England. Advantages and disadvantages are mostly consistent with evidence-based estimates. In contrast to the CCORE (Australian) evidencebased estimates, the Malthus model incorporates surgical rates and patient factors such as age, co-morbidities, and preferences (15).

CBB assumes the ORUR to be the ARUR of benchmark populations with optimal access to RT and appropriate decision making. The primary advantage of CBB is that it is based on real-world data. Clinical decisions regarding RT utilization may appropriately deviate from guidelines based on patient factors such as co-morbidities and preferences, and this cannot always be accounted for using other methods to estimate ORUR (32). In the study using CBB with Ontario, Canada data, the benchmark population was identified to be patients diagnosed at cancer centres with an associated RT facility (16). The one-year and lifetime ORUR based on the benchmark population were $54 \%$ and $62 \%$, compared to $45 \%$ and an estimated $52 \%$ in the overall Ontario population. A weakness of this model is that no benchmark population can indeed provide optimal access to RT and decision-making. Additionally, unrecognized barriers to RT may result in underestimation of ORUR, while incentives to provide RT may result in overestimation. Another weakness of CBB is that the estimate cannot be easily modified for changes in indications for RT or epidemiological data.

Additional factors need to be considered from the data presented herein. The Malthus model and CBB produced lower ORUR estimates of $61-62 \%$ compared to the CCORE evidence-based estimates of $77-82 \%$, and these were closer to the reported ARURs. One hypothesis for this observed difference may be that patient age, co-morbidities and preferences are reflected in the Malthus model and CBB, but not in the CCORE evidence-based estimates. Lung cancer patients frequently are older, with more comorbidities and lower performance status. As such, even if RT may be 'indicated', patients may elect not to undergo RT, or referring physicians may deem a patient not eligible for RT $(14,32)$.

ARUR data is limited by the unspecified or short observation period after diagnosis, and inconsistent 
Table 4 Studies reporting curative intent ARUR in lung cancer patients

\begin{tabular}{|c|c|c|c|c|c|c|c|}
\hline Author [year] & Diagnosis & $\begin{array}{l}\text { Number } \\
\text { diagnosed }\end{array}$ & Cancer registry & $\begin{array}{l}\text { Year of } \\
\text { diagnosis }\end{array}$ & Curative-intent ARUR & Note & $\begin{array}{l}\text { Time of curative- } \\
\text { intent ARUR }\end{array}$ \\
\hline $\begin{array}{l}\text { Chalubinska- } \\
\text { Fendler [2015] }\end{array}$ & $\begin{array}{l}\text { Lung } \\
\text { cancer }\end{array}$ & 1,307 & Central Poland & 2009-2012 & $\begin{array}{l}\text { 2009: 13\%; 2010: } \\
\text { 14\%; 2011: 12\%; } \\
\text { 2012: } 15 \%\end{array}$ & - & 2009-2012 \\
\hline Møller [2018] & $\begin{array}{l}\text { Lung } \\
\text { cancer }\end{array}$ & 139,709 & England & 2010-2013 & $8 \%$ & $\begin{array}{l}\text { Radical RT defined } \\
\text { as } \geq 15 \#\end{array}$ & $\begin{array}{l}\text { Within } 1 \text { year of } \\
\text { diagnosis }\end{array}$ \\
\hline Carrato [2014] & NSCLC & 3,508 & $\begin{array}{l}\text { Prospective study } \\
\text { of } 182 \text { cancer } \\
\text { centres in Belgium, } \\
\text { France, Germany, } \\
\text { Turkey, Greece, } \\
\text { Italy, Portugal and } \\
\text { Spain }\end{array}$ & $\begin{array}{l}\text { January- } \\
\text { March } 2009\end{array}$ & $\begin{array}{l}\text { Stage I: } 12 \% \text {; stage } \\
\text { II: } 22 \% \text {; stage III: } \\
\text { 33\%; stage IV: } 6 \% \text {; } \\
\text { overall: } 16 \%\end{array}$ & - & $\begin{array}{l}\text { Followed } \\
\text { prospectively } \\
\text { for a minimum } \\
\text { of } 1 \text { year or until } \\
\text { death }\end{array}$ \\
\hline Corso [2015] & $\begin{array}{l}\text { NSCLC, } \\
\text { stage I }\end{array}$ & 113,312 & USA (NCDB) & 2003-2011 & $\begin{array}{l}\text { 2009: black }=7 \% \text {, } \\
\text { white }=8 \% ; 2010: \\
\text { black }=10 \% \text {, white } \\
=11 \% ; 2011: \text { black } \\
=10 \% \text {, white }=13 \%\end{array}$ & $\begin{array}{l}\text { ARUR for SBRT, } \\
\text { defined as } B E D_{10} \text { of } \\
70 \text { to } 200 \text { Gy, in } \leq 7 \#\end{array}$ & 2003-2011 \\
\hline
\end{tabular}

ARUR, actual radiotherapy utilization rate; RT, radiotherapy; \#, fraction; SCLC, small-cell lung cancer; NCDB, National Cancer Database; $\mathrm{SBRT}$, stereotactic body radiotherapy; $\mathrm{BED}_{10}$, biological effective dose; Gy, Gray; EBRT, external beam radiotherapy; NSCLC, non-small cell lung cancer.

methods used to calculate ARUR (33). However, despite the lack of measured lifetime ARUR, there is clear underutilization of RT for lung cancer. Lifetime ARUR in Ontario, Canada, was estimated using the MCUT method to be $52 \%$ (16) and Lievens et al. reported 4- to 5-year ARUR of $46 \%$ (14), compared to lifetime ORUR of $61 \%$ to $82 \%$. One-year ORUR based on CBB was $54 \%$ (16), compared to reported one-year ARUR of $44 \%$ to $46 \%$. The available 1-year ARUR do not approximate lifetime
ARUR, as close to half of patients who die of lung cancer require RT in their last year or two years of life $(24,25)$. Long-term ARUR may be especially important in the era of increasingly effective systemic therapies. As immunotherapy following chemoradiation is now considered the standard of care for unresectable locally advanced NSCLC (34), and as immunotherapy and targeted therapies have resulted in survival improvements in metastatic lung cancer, further research focusing on lifetime ARUR in advanced lung 
cancer is warranted.

In addition to research of ARUR in advanced lung cancers, other gaps include the limited information for ARUR in LMICs, where the majority of patients with lung cancer live (35), and in indigenous populations. The majority of existing ARUR and ORUR literature is from North America, Australia or Europe. RT development is crucial in LMICs due to the increased lung cancer mortality (36) and the very limited access to surgery (37) and systemic therapy compared to high-income countries (HIC). While we cannot exclude the possibility that data for LMICs may be available in publications in other languages, another barrier for this type of research is the underdevelopment of population-based cancer registries in some areas. As an example, in Africa, Asia, and Central and South America, $2 \%, 6 \%$ and $8 \%$ of the regional populations were included in robust cancer registries, compared to $95 \%$ in North America (38). Even within HICs, ARUR data are not available for indigenous populations, who compared to nonindigenous patients from the same country, have increased risk of cancer mortality (39). Further development of cancer registries and calculation of ORUR and ARUR where data are available will allow for more accurate estimation of unmet RT needs.

\section{Conclusions}

Based on this systematic review, lifetime ORUR for lung cancer patients ranged from $61 \%$ to $82 \%$. ORUR of $61-62 \%$ based on CBB and the Malthus model are closer to ARUR compared to evidence-based estimates. Available ARUR data suggest an underutilization of RT in all populations. Almost all data were from North America, Australia, or Europe. No ORUR or ARUR for LMICs were reported.

\section{Acknowledgments}

None.

\section{Footnote}

Conflicts of Interest: Dr. Louie has received honoraria from Varian Medical Systems Inc. and AstraZeneca. The other authors have no conflicts of interest to declare.

Ethical Statement: The authors are accountable for all aspects of the work in ensuring that questions related to the accuracy or integrity of any part of the work are appropriately investigated and resolved.

\section{References}

1. Bray F, Ferlay J, Soerjomataram I, et al. Global cancer statistics 2018: GLOBOCAN estimates of incidence and mortality worldwide for 36 cancers in 185 countries. CA Cancer J Clin 2018;68:394-424.

2. NCCN Guidelines Version 5. Non-Small Cell Lung Cancer [Internet] 2019 [cited 2019 Aug 3]. Available online: https:// www.nccn.org/professionals/physician_gls/pdf/nscl.pdf

3. NCCN Guidelines Version 12019 Small Cell Lung Cancer [Internet] 2019 [cited 2019 Aug 3]. Available online: https://www.nccn.org/professionals/physician_gls/ pdf/sclc_blocks.pdf

4. Früh M, De Ruysscher D, Popat S, et al. Small-cell lung cancer (SCLC): ESMO Clinical Practice Guidelines for diagnosis, treatment and follow-up. Ann Oncol 2013;24:vi99-105.

5. Postmus PE, Kerr KM, Oudkerk M, et al. Early and locally advanced non-small-cell lung cancer (NSCLC): ESMO Clinical Practice Guidelines for diagnosis, treatment and follow-up. Ann Oncol 2017;28:iv1-21.

6. Planchard D, Popat S, Kerr K, et al. Metastatic non-small cell lung cancer: ESMO Clinical Practice Guidelines for diagnosis, treatment and follow-upt. Ann Oncol 2018;29:iv192-237.

7. Atun R, Jaffray DA, Barton MB, et al. Expanding global access to radiotherapy. Lancet Oncol 2015;16:1153-86.

8. Batumalai V, Shafiq J, Gabriel G, et al. Impact of radiotherapy underutilisation measured by survival shortfall, years of potential life lost and disability-adjusted life years lost in New South Wales, Australia. Radiother Oncol 2018;129:191-5.

9. Liberati A, Altman DG, Tetzlaff J, et al. The PRISMA statement for reporting systematic reviews and metaanalyses of studies that evaluate health care interventions: explanation and elaboration. J Clin Epidemiol 2009;62:e1-34.

10. Barton MB, Jacob S, Shafiq J, et al. Estimating the demand for radiotherapy from the evidence: a review of changes from 2003 to 2012. Radiother Oncol 2014;112:140-4.

11. Shafiq J, Hanna TP, Vinod SK, et al. A Populationbased Model of Local Control and Survival Benefit of Radiotherapy for Lung Cancer. Clin Oncol (R Coll 
Radiol) 2016;28:627-38.

12. Wong K, Delaney GP, Barton MB. Evidence-based optimal number of radiotherapy fractions for cancer: A useful tool to estimate radiotherapy demand. Radiother Oncol 2016;119:145-9.

13. Borras JM, Barton M, Grau C, et al. The impact of cancer incidence and stage on optimal utilization of radiotherapy: Methodology of a population based analysis by the ESTRO-HERO project. Radiother Oncol 2015;116:45-50.

14. Lievens Y, De Schutter H, Stellamans K, et al. Radiotherapy access in Belgium: How far are we from evidence-based utilisation? Eur J Cancer 2017;84:102-13.

15. Round CE, Williams MV, Mee T, et al. Radiotherapy Demand and Activity in England 2006-2020. Clin Oncol (R Coll Radiol) 2013;25:522-30.

16. Mackillop WJ, Kong W, Brundage M, et al. A Comparison of Evidence-Based Estimates and Empirical Benchmarks of the Appropriate Rate of Use of Radiation Therapy in Ontario. Int J Radiat Oncol Biol Phys 2015;91:1099-107.

17. Asli LM, Kvaløy SO, Jetne V, et al. Utilization of radiation therapy in Norway after the implementation of the national cancer plan--a national, population-based study. Int J Radiat Oncol Biol Phys 2014;90:707-14.

18. Chalubinska-Fendler J, Fendler W, Spych M, et al. Availability and outcomes of radiotherapy in Central Poland during the 2005-2012 period - an observational study. BMC Cancer 2015;15:214.

19. McLaughlin PY, Kong W, de Metz C, et al. Do radiation oncology outreach clinics affect the use of radiotherapy? Radiother Oncol 2018;127:143-9.

20. Seo YS, Kim MS, Kang JK, et al. The Clinical Utilization of Radiation Therapy in Korea between 2011 and 2015. Cancer Res Treat 2018;50:345-55.

21. Carrato A, Vergnenègre A, Thomas $M$, et al. Clinical management patterns and treatment outcomes in patients with non-small cell lung cancer (NSCLC) across Europe: EPICLIN-Lung study. Curr Med Res Opin 2014;30:447-61.

22. Haque W, Szeja S, Tann A, et al. Changes in Treatment Patterns and Overall Survival in Patients With EarlyStage Non-Small Cell Lung Cancer in the United States After the Incorporation of Stereotactic Ablative Radiation Therapy: A Population-based Analysis. Am J Clin Oncol 2018;41:259-66.

23. Ahmed Z, Kujtan L, Kennedy KF, et al. Disparities in the Management of Patients With Stage I Small Cell
Lung Carcinoma (SCLC): A Surveillance, Epidemiology and End Results (SEER) Analysis. Clin Lung Cancer 2017;18:e315-25.

24. Huang J, Wai ES, Lau F, et al. Palliative radiotherapy utilization for cancer patients at end of life in British Columbia: retrospective cohort study. BMC Palliat Care 2014;13:49.

25. Åsli LM, Myklebust TÅ, Kvaløy SO, et al. Factors influencing access to palliative radiotherapy: a Norwegian population-based study. Acta Oncol 2018;57:1250-8.

26. Møller H, Coupland VH, Tataru D, et al. Geographical variations in the use of cancer treatments are associated with survival of lung cancer patients. Thorax 2018;73:530-7.

27. Stahl JM, Corso CD, Verma V, et al. Trends in stereotactic body radiation therapy for stage I small cell lung cancer. Lung Cancer 2017;103:11-6.

28. Corso CD, Park HS, Kim AW, et al. Racial disparities in the use of SBRT for treating early-stage lung cancer. Lung Cancer 2015;89:133-8.

29. Brada M, Ball C, Mitchell S, et al. Improving outcomes in non-small cell lung cancer; population analysis of radical radiotherapy. Radiother Oncol 2019;132:204-10.

30. Grover S, Xu MJ, Yeager A, et al. A Systematic Review of Radiotherapy Capacity in Low- and Middle-Income Countries. Front Oncol 2015;4:380.

31. Tyldesley S, Boyd C, Schulze K, et al. Estimating the need for radiotherapy for lung cancer: an evidence-based, epidemiologic approach. Int J Radiat Oncol Biol Phys 2001;49:973-85.

32. Vinod SK, Sidhom MA, Delaney GP. Do Multidisciplinary Meetings Follow Guideline-Based Care? J Oncol Pract 2010;6:276-81.

33. Yap ML, O'Connell DL, Goldsbury D, et al. Comparison of four methods for estimating actual radiotherapy utilisation using the 45 and Up Study cohort in New South Wales, Australia. Radiother Oncol 2019;131:14-20.

34. Antonia SJ, Villegas A, Daniel D, et al. Overall Survival with Durvalumab after Chemoradiotherapy in Stage III NSCLC. N Engl J Med 2018;379:2342-50.

35. Forman D, Bray F, Brewster DH, et al. Cancer incidence in five continents Volume X. Lyon: International Agency for Research on Cancer; 2013.

36. Torre LA, Siegel RL, Jemal A. Lung Cancer Statistics. In: Advances in experimental medicine and biology 2016:1-19.

37. Alkire BC, Raykar NP, Shrime MG, et al. Global access to surgical care: a modelling study. Lancet Glob Health 2015;3:e316-23. 
38. Bray F, Ferlay J, Laversanne M, et al. Cancer Incidence in Five Continents: Inclusion criteria, highlights from Volume $\mathrm{X}$ and the global status of cancer registration. Int J Cancer 2015;137:2060-71.

Cite this article as: Liu W, Liu A, Chan J, Boldt RG, MunozSchuffenegger P, Louie AV. What is the optimal radiotherapy utilization rate for lung cancer? - a systematic review. Transl Lung Cancer Res 2019;8(Suppl 2):S163-S171. doi: 10.21037/ tlcr.2019.08.12
39. Rodin D, Longo J, Sherertz T, et al. Mobilising Expertise and Resources to Close the Radiotherapy Gap in Cancer Care. Clin Oncol (R Coll Radiol) 2017;29:135-40. 